\title{
Experimental Ammonia-free Phosphate-bonded Investments using $\mathrm{Mg}\left(\mathrm{H}_{2} \mathrm{PO}_{4}\right)_{2}$ Solution
}

\author{
Shigeyuki TAKASHIBA, Zutai ZHANG ${ }^{1}$ and Yukimichi TAMAKI \\ Department of Oral Biomaterials \& Technology \\ Showa University School of Dentistry \\ 1-5-8 Hatanodai, Shinagawa-ku, Tokyo 142-8555, Japan \\ ${ }^{1}$ Department of Operative Dentistry \\ Showa University School of Dentistry \\ 2-1-1 Kitasenzoku, Ohta-ku, Tokyo 145-8515, Japan
}

Received July 15, 2002/Accepted September 30, 2002

\begin{abstract}
In our previous study, we investigated ammonia-free phosphate-bonded investments using $\mathrm{Mg}$ $\left(\mathrm{H}_{2} \mathrm{PO}_{4}\right)_{2}$ powder. The purpose of the present study was to attempt usage of $50 \mathrm{wt} \% \mathrm{Mg}$ $\left(\mathrm{H}_{2} \mathrm{PO}_{4}\right)_{2}$ solution instead of powder. Magnesium oxide $(\mathrm{MgO})$ was prepared as a binder and cristobalite was selected as a refractory. After arranging six kinds of experimental investments (A-F) with different cristobalite/ $\mathrm{MgO}$ ratios, the fundamental properties of the dental investments were examined. The properties of the molds were influenced by the amount of $\mathrm{MgO}$. Decreases in $\mathrm{MgO}$ showed lower mold strengths, longer setting time and larger setting expansion. According to XRD analysis, the peaks of $\mathrm{MgH}\left(\mathrm{PO}_{4}\right)_{3} \cdot 3 \mathrm{H}_{2} \mathrm{O}$ newly formed, cristobalite and $\mathrm{MgO}$ were detected in the $\mathrm{A}$ set, but $\mathrm{MgO}$ peaks in $\mathrm{F}$ set were reduced. On the other hand, the surface of $\mathrm{F}$ was entirely covered by phosphorus. From these results, it was found that the usage of $\mathrm{Mg}\left(\mathrm{H}_{2} \mathrm{PO}_{4}\right)_{2}$ solution was possible for ammonia-free investments.
\end{abstract}

Key words: Phosphate-bonded investment, Ammonia-free binder, Mechanical property

\section{INTRODUCTION}

Dental phosphate-bonded investments have typically been utilized to cast high melting point alloys like base metals ${ }^{1)}$. Recently, they were also available for titanium casting $^{2-4)}$, high-karat gold alloys for veneering with dental porcelain and the accelerated casting method ${ }^{5)}$. However, it is well-known that this type of investment leads to a poorer environment from which ammonia gas was released from the mold through the casting procedure ${ }^{6,7)}$. The ammonia gas was produced by dissolution of ammonia dihydrogen magnesium phosphate during firing that was produced at setting between magnesium oxide and ammonium dihydrogen phosphate. This ammonia is harmful for humans. In addition, operators may also be affected by the ammonia gas.

We have been developing a phosphate-bonded investment without ammonium dihydrogenphosphate ${ }^{8)}$. This type of investment is expected to have a great advantage for the health of laboratory workers because the compounds do not release ammonia gas. We previously reported that experimental ammonia-free phosphatebonded investments with $\mathrm{Mg}\left(\mathrm{H}_{2} \mathrm{PO}_{4}\right)_{2}$ were desirable for dental casting investments based on some properties such as strength, dimensional change and manipulation ${ }^{9}$.

In our previous study ${ }^{9)}$, we tested $\mathrm{Mg}\left(\mathrm{H}_{2} \mathrm{PO}_{4}\right)_{2}$ powder by mixing with both 
cristobalite and $\mathrm{MgO}$ powder. However, $\mathrm{Mg}\left(\mathrm{H}_{2} \mathrm{PO}_{4}\right)_{2}$ solution was expected to be better than $\mathrm{Mg}\left(\mathrm{H}_{2} \mathrm{PO}_{4}\right)_{2}$ powder since $\mathrm{Mg}\left(\mathrm{H}_{2} \mathrm{PO}_{4}\right)_{2}$ solution was entirely ionized into water before mixing. In addition, the liquid condition was useful for long-term storage because the powder easily degenerates in a moist environment. The purpose of this study was to investigate the effects of $\mathrm{Mg}\left(\mathrm{H}_{2} \mathrm{PO}_{4}\right)_{2}$ solution for experimental ammonia-free phosphate-bonded investments.

\section{MATERIALS AND METHODS}

$\mathrm{Mg}\left(\mathrm{H}_{2} \mathrm{PO}_{4}\right)_{2}$ solution (50 wt\% concentration: Ychem Co., Ltd, Tokyo, Japan) and $\mathrm{MgO}$ (\#200 mesh pass: Tateho Chemical Industry Co., Ltd, Himeji, Japan) powder were prepared in this study as binders. Cristobalite powder (Average particle size: $9.1 \mu \mathrm{m}$, Tatsumori Co., Ltd, Tokyo, Japan) was selected as the refractory.

The $\mathrm{L} / \mathrm{P}$. ratio was set at 0.4 from tentative mixing. The six kinds of investment powders composed of cristobalite and $\mathrm{MgO}$ were each adjusted to $100 \mathrm{~g}$ as shown in Table 1, then $\mathrm{Mg}\left(\mathrm{H}_{2} \mathrm{PO}_{4}\right)_{2}$ solution was fixed to $40 \mathrm{ml}$. Under these conditions, they were mixed for 30 seconds by hand and then automatically mixed for an additional 30 seconds with a vacuum mixing apparatus. All of specimens were prepared from $100 \mathrm{~g}$ powder mixed with $40 \mathrm{ml} \mathrm{Mg}\left(\mathrm{H}_{2} \mathrm{PO}_{4}\right)_{2}$ solution. Six experimental investments with different ratios were made.

Cylinder shaped specimens with $10 \mathrm{~mm}$ diameter and $20 \mathrm{~mm}$ height were prepared for a compressive test. Five specimens were formed at 24 hours after mixing and the other five specimens were heated from room temperature to $900^{\circ} \mathrm{C}$ at 24 hours after mixing. Testing was performed using a universal testing machine (Instron Model 1125, Instron, Kawasaki, Japan) with a cross-head speed of $1 \mathrm{~mm} /$ minute.

An initial set of the mold was checked using a Vicat needle penetration test according to JIS T-6601 ${ }^{10)}$. A wax ring with $50 \mathrm{~mm}$ diameter and $20 \mathrm{~mm}$ height was planted on the glass, and mixed slurry was poured into the ring with weak vibration. Setting time was recorded when the hardened investment could be penetrated $1 \mathrm{~mm}$ by the needle three times for each investment.

According to our previous study ${ }^{9}$, setting expansion at two hours after mixing was measured in the paraffin wax ring with $25 \mathrm{~mm}$ diameter and $30 \mathrm{~mm}$ height. Immediately after checking the initial setting, a thin glass plate was placed on top of

Table 1 Experimental investments tested in this study

\begin{tabular}{cccc}
\hline Investment & $\begin{array}{c}50 \% \text { solution } \\
(\mathrm{ml})\end{array}$ & $\begin{array}{c}\mathrm{MgO} \\
(\mathrm{g})\end{array}$ & $\begin{array}{c}\text { Cristobalite } \\
(\mathrm{g})\end{array}$ \\
\hline $\mathrm{A}$ & 40 & 26 & 74 \\
$\mathrm{~B}$ & 40 & 23 & 77 \\
$\mathrm{C}$ & 40 & 20 & 80 \\
$\mathrm{D}$ & 40 & 17 & 83 \\
$\mathrm{E}$ & 40 & 14 & 86 \\
$\mathrm{~F}$ & 40 & 11 & 89 \\
\hline
\end{tabular}


the mold followed by digitizing using a precision micrometer sensor (MINICOM, Tokyo Seimitsu, Co., Ltd, Tokyo, Japan). The value was estimated as a transition ratio of the original height. The values of each investment were calculated as the mean of three measurements.

The thermal behavior of the specimen ( $6 \mathrm{~mm}$ diameter and $12 \mathrm{~mm}$ height) from room temperature to $900^{\circ} \mathrm{C}$ with $10^{\circ} \mathrm{C} /$ minute at 24 hours after mixing was drawn on the display using a thermal analyzing apparatus (Thermo Plus 8310, Rigaku, Shojima, Japan). A detecting rod was loaded with $5 \mathrm{~g}$ weight for each specimen while testing. Thermal expansion was automatically calculated using the transition ratio from the original height. Three specimens were prepared for this test and the mean value at $900^{\circ} \mathrm{C}$ was calculated.

Each composition of the set investments was identified by X-ray diffraction analysis (XRD 6100, Shimadzu, Hadano, Japan) using $\mathrm{Cu}-\mathrm{K} \alpha$ radiation. $\mathrm{XRD}$ was run at $40 \mathrm{kV}$ and $30 \mathrm{~mA}$ with a scanning speed of $5^{\circ} /$ minute and a scanning range of $15-80^{\circ}$. Investments milled after setting were prepared for this analysis.

After the tested investment slurry was poured into a plastic ring (15 mm diameter and $5 \mathrm{~mm}$ height), specimens were prepared. The bottom surfaces of both investment $\mathrm{A}$ and $\mathrm{F}$ were observed using a scanning electron microscope apparatus (S2500CX, Hitachi, Hitachi, Japan) with an accelerated voltage of $20 \mathrm{kV}$ and an electric current of $0.1 \mathrm{nA}$. Furthermore, an elemental distribution for the same surfaces as above was demonstrated using an energy disperse X-ray analysis (EDX; Quantum $\Delta-4$, Kevex) with an accelerated voltage of $15 \mathrm{kV}$ and an electric current of $0.1 \mathrm{nA}$.

The fundamental properties of the experimental investments were statistically analyzed by One-way ANOVA $(\alpha=0.05)$ and Scheffe's test.

\section{RESULTS}

The results of setting time are shown in Fig. 1. According to the decrease in the

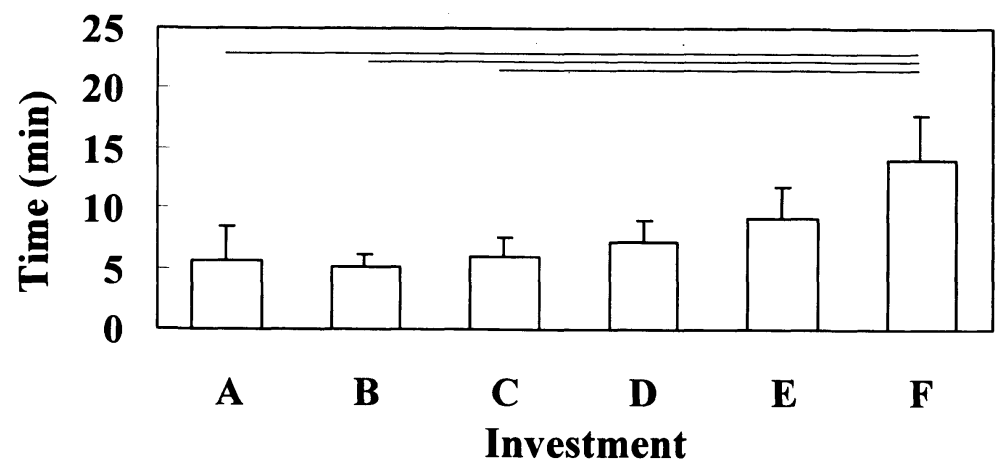

Fig. 1 Setting time of experimental investments.

Vertical bars indicate the standard deviation. Horizontal bars indicate the significant difference at the level of $5 \%$. 


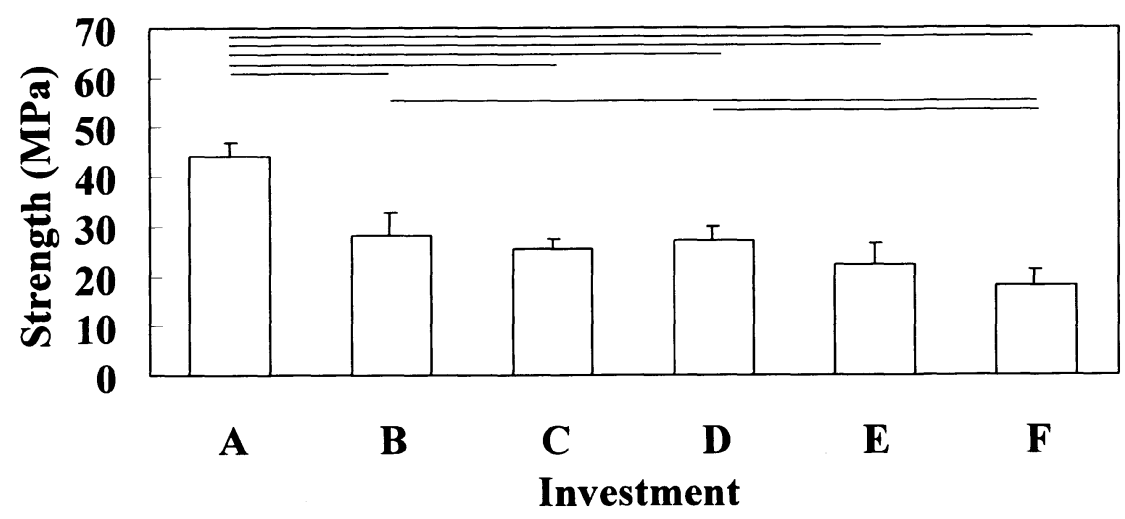

Fig. 2 Green compressive strengths of experimental investments. Vertical bars indicate the standard deviation. Horizontal bars indicate the significant difference at the level of $5 \%$.

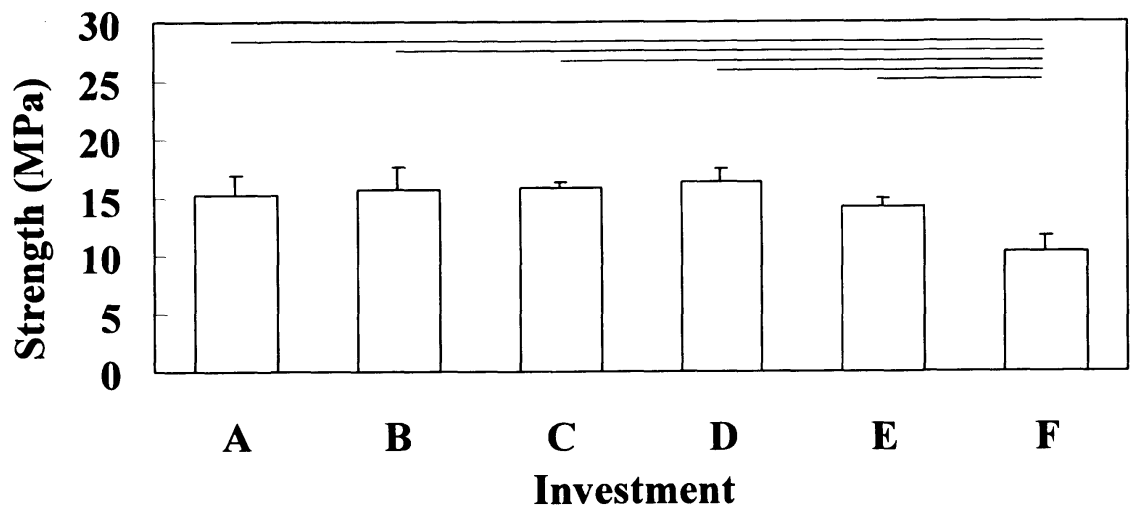

Fig. 3 Fired compressive strengths of experimental investments.

Vertical bars indicate the standard deviation. Horizontal bars indicate the significant difference at the level of $5 \%$.

$\mathrm{MgO}$ contents, the molds clearly set later and there were significant differences among them $(p<0.05)$. The setting time of $F$ was the longest with a value of 14.17 minutes.

The results of compressive strength are shown in Fig. 2 and 3 . Investment $A$ showed 44.26 $\pm 2.86 \mathrm{MPa}$, which was significantly higher $(\mathrm{p}<0.05)$ than those of the other experimental investments on green strength. The green strength showed gradual tendency to decrease with the decrease in $\mathrm{MgO}$. On the other hand, the fired strength of $\mathrm{A}$ was $15.19 \pm 1.74 \mathrm{MPa}$, and there were no significant differences among the investments tested except for $\mathrm{F}$. The fired strength of $\mathrm{F}$ was $10.34 \pm 1.3 \mathrm{MPa}$, which was the smallest among the experimental investments and significantly lower than those of the other investments tested. 


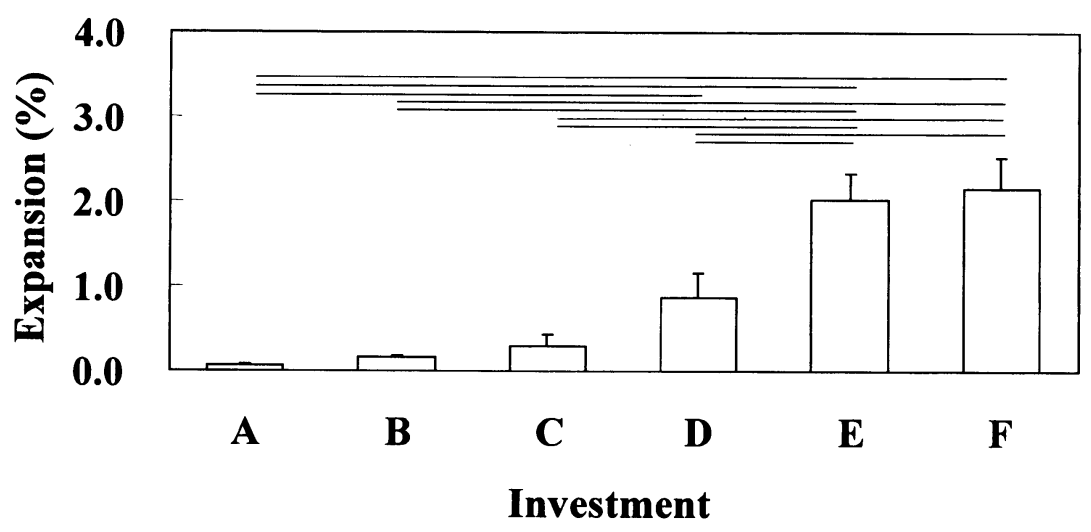

Fig. 4 Setting expansion of the investments tested.

Vertical bars indicate the standard deviation. Horizontal bars indicate the significant difference at the level of $5 \%$.

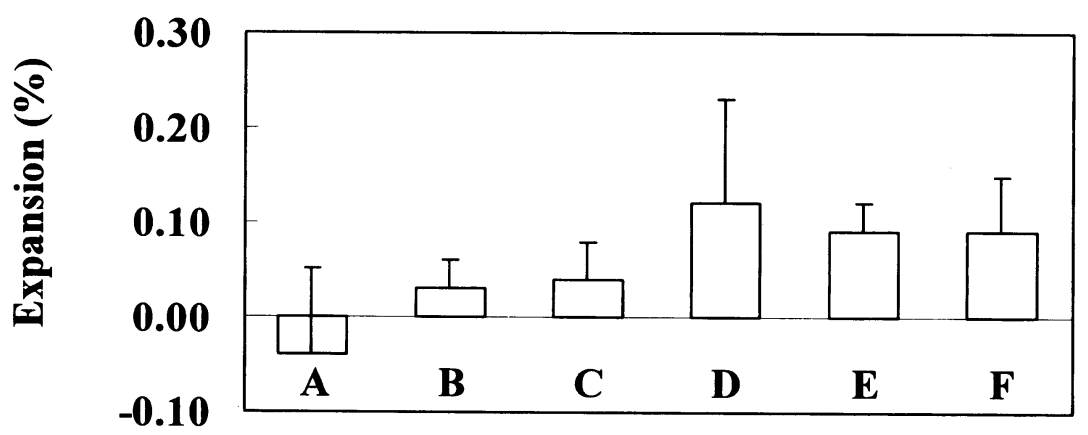

\section{Investment}

Fig. 5 Thermal expansion of the investments tested. Vertical bars indicate the standard deviation.

Fig. 4 shows the results of the setting expansion. There were clear significant differences among them $(\mathrm{p}<0.05)$. We found that less $\mathrm{MgO}$ powder was effective to expand the experimental molds at setting. In particular, investment $\mathrm{E}$ and $\mathrm{F}$ were significantly superior to other investments on setting expansion with the values of $\mathrm{E}$ and $\mathrm{F}$ were $2.01 \pm 0.31 \%$ and $2.15 \pm 0.36 \%$, respectively. Each expansion of other investments was less than $1 \%$. Investment $A$, whose value was $0.06 \%$, showed the smallest expansion at setting.

The results of the thermal expansion up to $900^{\circ} \mathrm{C}$ are shown in Fig. 5. There were no significant differences among them $(\mathrm{p}<0.05)$. Investment $\mathrm{A}$ with the least cristobalite showed a slightly shifted contraction at $900^{\circ} \mathrm{C}$. A slight expansion within $0.05 \%$ was recognized in $\mathrm{B}$ and $\mathrm{C}$. However, D expanded $0.18 \%$ and showed the largest thermal expansion in the investments tested. Those of $\mathrm{E}$ and $\mathrm{F}$ were about $0.1 \%$. 


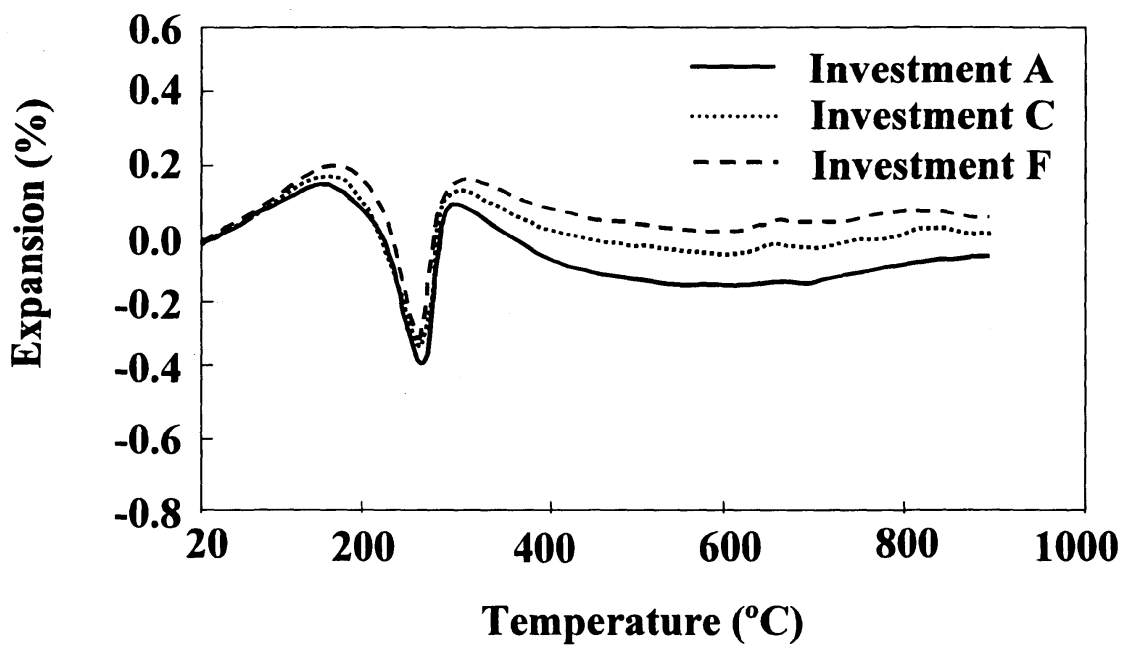

Fig. 6 Thermal behavior of the experimental investments.

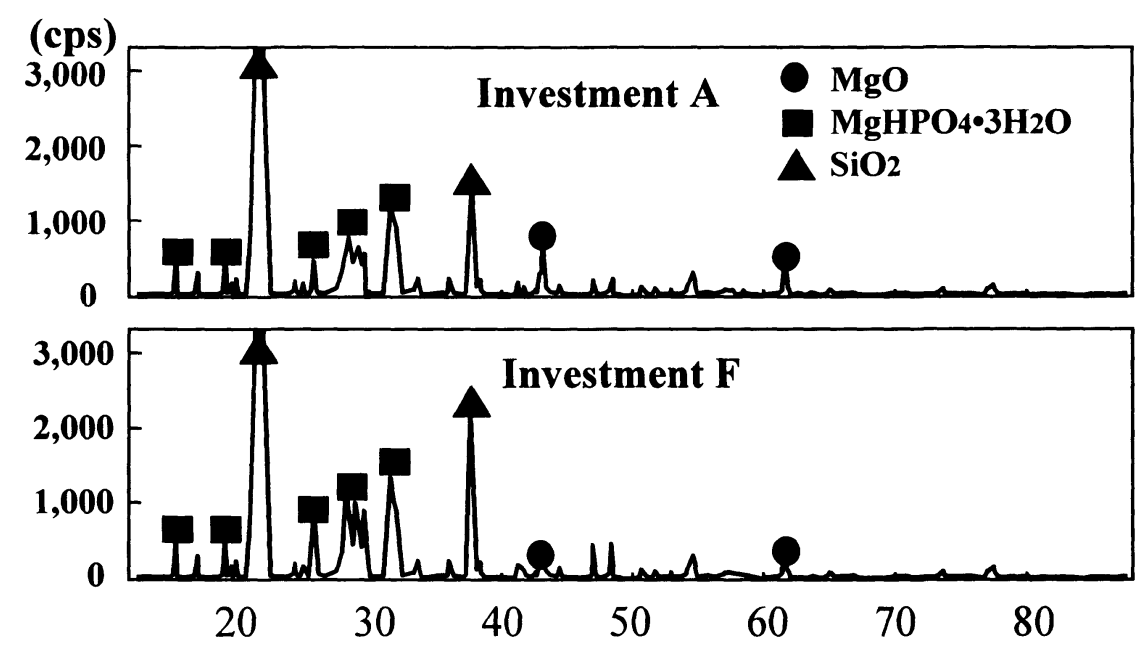

Fig. 7 XRD analysis of both $\mathrm{A}$ and $\mathrm{F}$.

The curves of three typical experimental investments while heating to $900^{\circ} \mathrm{C}$ are shown in Fig. 6. There was a steep down turn at $160^{\circ} \mathrm{C}$ in every investment. After reaching the deepest point, each specimen suddenly increased from $260-280^{\circ} \mathrm{C}$. Heating over $400^{\circ} \mathrm{C}$, no large expansion appeared.

Fig. 7 shows the result of XRD analysis for both A and F. A new compound (Magnesium dihidrogen phosphate: $\mathrm{MgH}\left(\mathrm{PO}_{4}\right)_{3} \cdot 3 \mathrm{H}_{2} \mathrm{O}$ ), cristobalite and residual $\mathrm{MgO}$ were detected from investment A. Although this new compound was also observed in the chart from $\mathrm{F}$, the $\mathrm{MgO}$ peak was weaker than those of investment $\mathrm{A}$.

SEM and BSE images of both $\mathrm{A}$ and $\mathrm{F}$ are shown in Fig. 8 and 9. Although the 


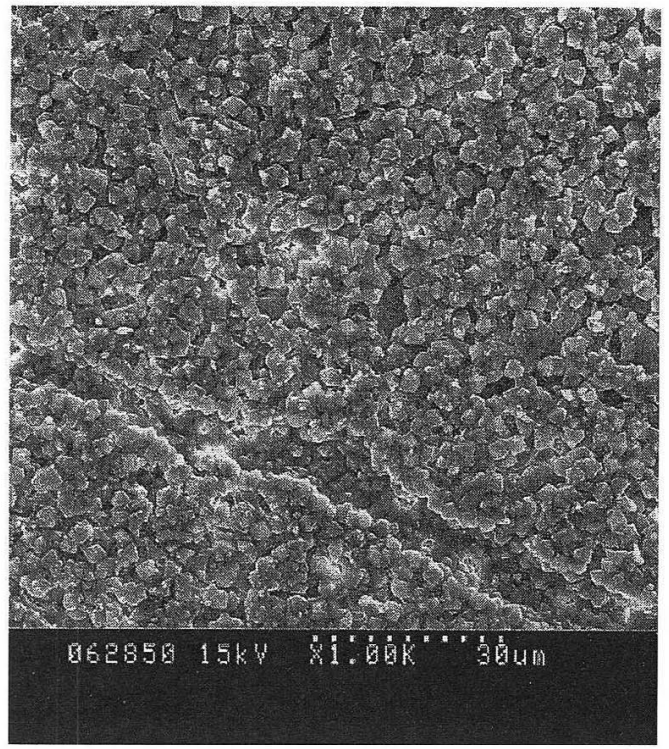

SEM

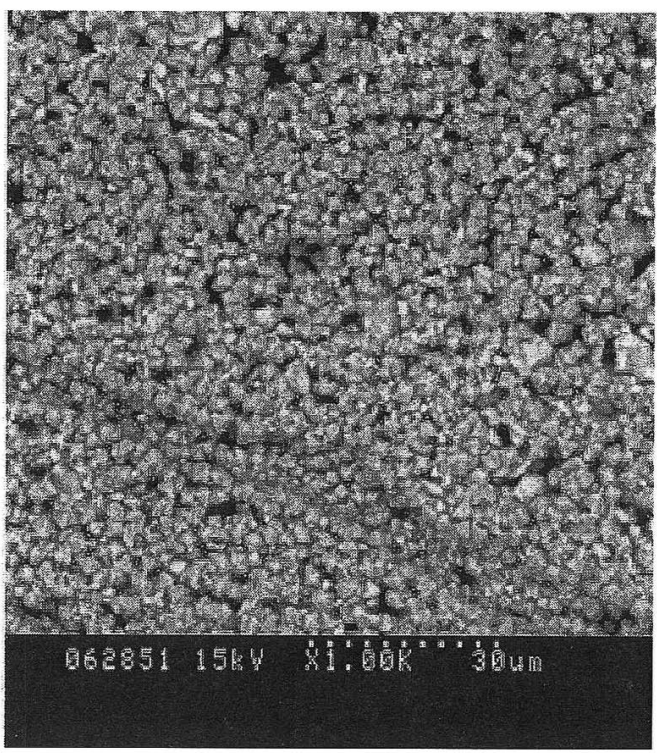

BSF:

Fig. 8 SEM and BSE image on the setting surface of A.

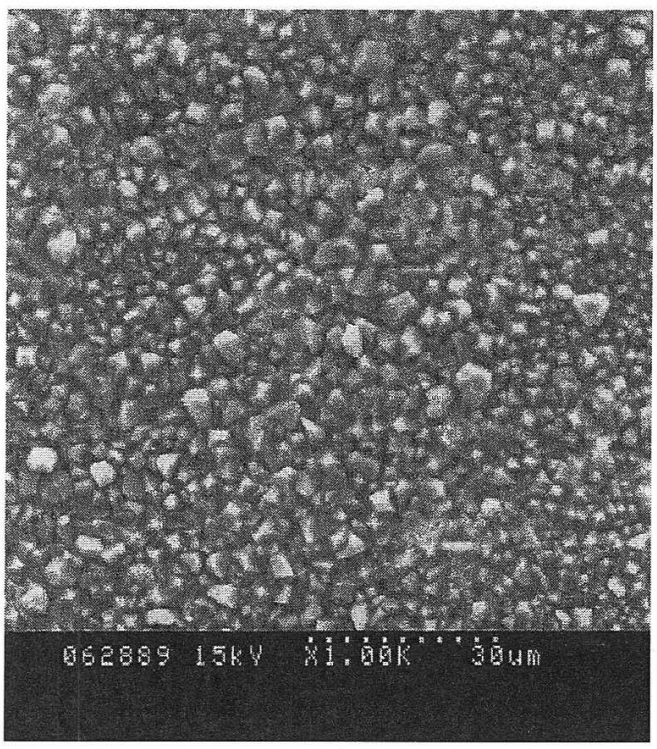

SEM

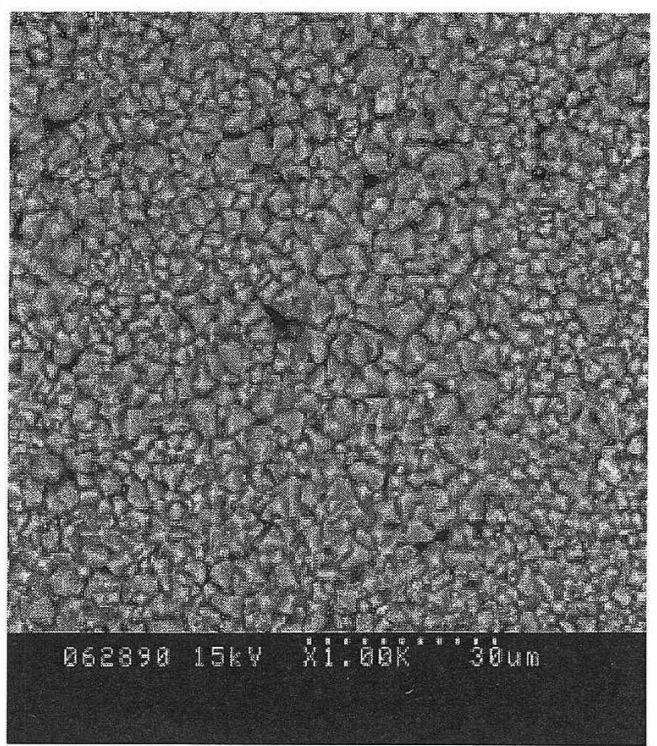

BSE

Fig. 9 SEM and BSE image on the setting surface of F. 
Investment A

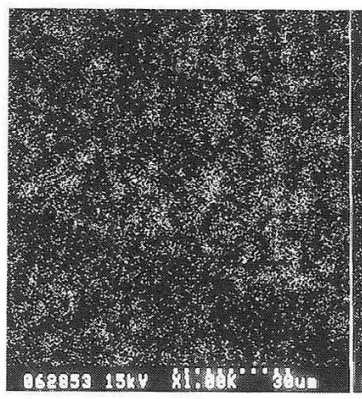

Si

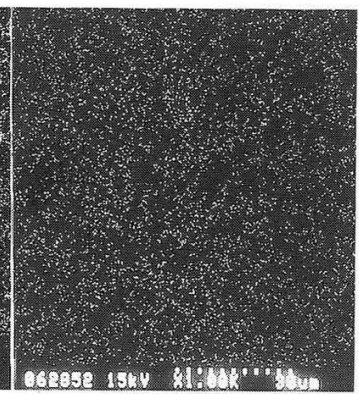

$\mathrm{P}$
Investment $\mathrm{F}$

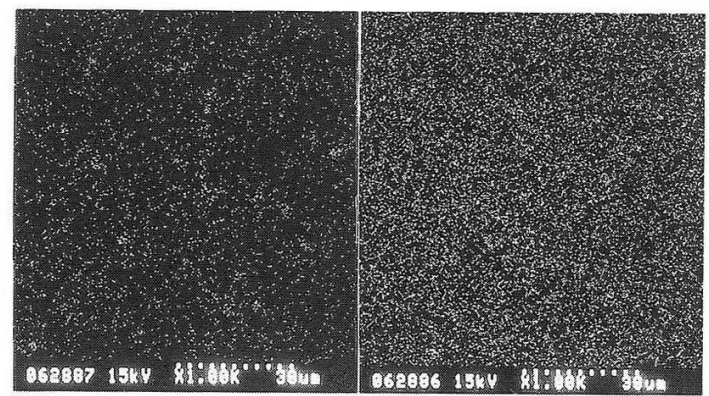

$\mathrm{Si}$

$\mathrm{P}$

Fig. 10 Mapping analyses on the setting surfaces of $\mathrm{A}$ and F.

surfaces of $\mathrm{A}$ were condensed by fine particles, the particles in $\mathrm{F}$ were clearly coarser than those in A. The mapping analyses of the set surface for both elements $\mathrm{Si}$ as $\mathrm{SiO}_{2}$ and $\mathrm{P}$ as phosphorus are shown in Fig. 10. Although A was strongly covered by $\mathrm{Si}$ and $\mathrm{P}$, more $\mathrm{P}$ was detected on the surface of $\mathrm{F}$.

\section{DISCUSSION}

We previously reported ${ }^{8,9)}$ that $\mathrm{Mg}\left(\mathrm{H}_{2} \mathrm{PO}_{4}\right)_{2}$ could successfully substitute $\mathrm{NH}_{4} \mathrm{H}_{2} \mathrm{PO}_{4}$ and would be acceptable as a dental phosphate-bonded investment. The composition of the experimental ammonia-free investments was very similar to conventional type. Although there were different kinds of powder in the investment, chemical reactions between binder materials did not occur without water. The setting reaction started from the ionization of the components by mixing with water or special liquid. $\mathrm{Mg}$ $\left(\mathrm{H}_{2} \mathrm{PO}_{4}\right)_{2}$ was easily water-soluble like $\mathrm{NH}_{4} \mathrm{H}_{2} \mathrm{PO}_{4}$. However, since cristobalite and $\mathrm{MgO}$ were entirely insoluble, the $\mathrm{Mg}\left(\mathrm{H}_{2} \mathrm{PO}_{4}\right)_{2}$ powder surrounded by fine particles may lose the opportunity to dissolve in water. In addition, the solution was clearly more stable than powder, except for vaporization. Therefore, $\mathrm{Mg}\left(\mathrm{H}_{2} \mathrm{PO}_{4}\right)_{2}$ solution was expected to overcome the shortcomings of $\mathrm{Mg}\left(\mathrm{H}_{2} \mathrm{PO}_{4}\right)_{2}$ powder as a binder.

The rate of $\mathrm{Mg}\left(\mathrm{H}_{2} \mathrm{PO}_{4}\right)_{2}$ for $\mathrm{MgO}$ increased in alphabetical order since the volume of the solution was constant at $40 \mathrm{ml}$. The molds became fragile alphabetically and took much time to set by the decrease in the $\mathrm{MgO} / \mathrm{Mg}\left(\mathrm{H}_{2} \mathrm{PO}_{4}\right)_{2}$ ratio, as shown in Fig. 1, 2 and 3. Investment $\mathrm{A}$ appeared to be difficult to apply for laboratory use because it was too brittle and set fast. These influences on the $\mathrm{MgO} / \mathrm{Mg}\left(\mathrm{H}_{2} \mathrm{PO}_{4}\right)_{2}$ ratio are consistent with our previous finding $\mathrm{s}^{8)}$. Consequently, we could assert that $\mathrm{MgO}$ played an important role for immediate setting and hardening.

Regarding the expansion of molds, the molds with less $\mathrm{MgO}$ such as $\mathrm{E}$ or $\mathrm{F}$ were found to be advantageous. In particular, they showed outstanding setting expansion. Furthermore, it was suggested to be also favorable for thermal expansion because less $\mathrm{MgO}$ equaled more cristobalite. However, each thermal expansion of the invest- 
ments tested did not appear to be adequate to compensate for the casting shrinkage when using a base metal ${ }^{11,12}$. It is suggested that this reason was due to the high $\mathrm{L} / \mathrm{P}$ ratio or some additives in the $\mathrm{Mg}\left(\mathrm{H}_{2} \mathrm{PO}_{4}\right)_{2}$ solution to maintain the quality.

In general, expansion of the commercial phosphate-bonded investments at setting was obtained from the new formation of the magnesium ammonium phosphate $\left(\mathrm{NH}_{4} \mathrm{MgPO}_{4} \cdot 6 \mathrm{H}_{2} \mathrm{O}\right)$ from the binders. If this theory was also applicable for the experimental ammonia-free investments, newly formed $\mathrm{MgH}\left(\mathrm{PO}_{4}\right)_{3} \cdot 3 \mathrm{H}_{2} \mathrm{O}^{8,13)}$ would make the molds larger. Considering the result in this study, sufficient $\mathrm{Mg}\left(\mathrm{H}_{2} \mathrm{PO}_{4}\right)_{2}$ was preferable for the formation of $\mathrm{MgH}\left(\mathrm{PO}_{4}\right)_{3} \cdot 3 \mathrm{H}_{2} \mathrm{O}$ because $\mathrm{E}$ and $\mathrm{F}$ expanded greater than other investments tested. This assumption was predictable from XRD analysis in Fig. 7. Although clear peaks of $\mathrm{MgO}$ in the $\mathrm{F}$ were too small to detect, peaks of $\mathrm{MgH}\left(\mathrm{PO}_{4}\right)_{3} \cdot 3 \mathrm{H}_{2} \mathrm{O}$ were slightly taller than those of $\mathrm{A}$. On the other hand, Fig. 8 and 9 show that crystalline-like particles on the surface of $F$ were clearly greater than those of A. Furthermore, the surface of $\mathrm{F}$ was mostly occupied by phosphorus, despite the high $\mathrm{SiO}_{2}$ content as shown in Table 1. Therefore, it was suggested that most of the $\mathrm{MgO}$ was consumed to form $\mathrm{MgH}\left(\mathrm{PO}_{4}\right)_{3} \cdot 3 \mathrm{H}_{2} \mathrm{O}$ by accelerating ionization of $\mathrm{Mg}\left(\mathrm{H}_{2} \mathrm{PO}_{4}\right)_{2}$. However, the possibility remains that the $\mathrm{MgO}$ added in $\mathrm{F}$ was merely insufficient. Thus, we will continue detailed investigations to clarify the mechanism of setting expansion.

Thermal expansion is as important as setting expansion to control precision casting. However, none of the experimental investments tested exhibited satisfactory expansion during heating. A large dimensional change similar to a V-shape was showed at approximately $250^{\circ} \mathrm{C}$ in the thermal expansion curves shown in Fig. 5 . This rapid descent was produced by the dehydration, the dissolution or amorphous $\mathrm{Mg}_{2} \mathrm{P}_{2} \mathrm{O}_{7}$ formation ${ }^{8,14)}$. The rapid ascent was produced by the routine phasetransition of cristobalite. However, the ordinary sharp expansion during $250-300^{\circ} \mathrm{C}$ might be offset by such a complex variation as mentioned above.

Judging from these results, the $50 \mathrm{wt} \% \mathrm{Mg}\left(\mathrm{H}_{2} \mathrm{PO}_{4}\right)_{2}$ solution tested has the possibility as an alternative to $\mathrm{Mg}\left(\mathrm{H}_{2} \mathrm{PO}_{4}\right)_{2}$ powder for dental investments. Moreover, $\mathrm{Mg}\left(\mathrm{H}_{2} \mathrm{PO}_{4}\right)_{2}$ solution was easy to handle for laboratory users as reported previously. However, we did not alter the concentration of the $\mathrm{Mg}\left(\mathrm{H}_{2} \mathrm{PO}_{4}\right)_{2}$ solution in this study. Typically, arbitrary colloidal silica solutions in aqueous suspension are available in dental laboratory use. In addition, the relation between the chemical reaction and the setting expansion remains unclarified. Therefore, further studies will be required to explore better composition of the $\mathrm{Mg}\left(\mathrm{H}_{2} \mathrm{PO}_{4}\right)_{2}$ solution.

\section{CONCLUSIONS}

1. The $50 \mathrm{wt} \% \mathrm{Mg}\left(\mathrm{H}_{2} \mathrm{PO}_{4}\right)_{2}$ solution could be applied as a liquid for experimental ammonia-free phosphate bonded investments.

2. With decreases in the amount of $\mathrm{MgO}$, the investments tested showed a tendency to have lower strength, longer setting time and greater setting expansion. Investment $\mathrm{A}$, which was composed of the highest $\mathrm{MgO}$ content in this test, showed the 
highest strength, fastest setting time and least setting expansion.

3 . Thermal expansion was not influenced by the amount of cristobalite. These were too small to compensate for casting shrinkage.

4. Setting expansion of the investments tested depended on the $\mathrm{MgO}$ content. $\mathrm{E}$ and $\mathrm{F}$ with less $\mathrm{MgO}$ showed the largest setting expansion of about $2 \%$ or greater. This was suggested to be due to the growth of $\mathrm{MgH}\left(\mathrm{PO}_{4}\right)_{3} \cdot 3 \mathrm{H}_{2} \mathrm{O}$ formed at setting.

5 . Investment $\mathrm{F}$ showed the possibility to be preferable as a dental phosphatebonded material because of the large setting expansion, suitable strength and sufficient manipulation time.

\section{REFERENCES}

1) Osborne, J.: Dental technology and materials for student, $7^{\text {th }}$ ed, Blackwell Scientific, 1979, 288-290.

2) Takahashi, J., Zhang, J. and Okazaki, M.: Castability and surface hardness of titanium cast plates obtained from experimental phosphate-bonded silica investment molds, Dent Mater $J$ 12(2) : 238-244, 1993.

3) Moriguchi, A., Omasa, Y., Kakimoto, K. and Gonda, Y.: Pure titanium denture base cast using phosphate-bonded investment - Improvement of reactive layes by coating method-, J Jpn Prosthodont Soc, 43(5) : 857-866, 1999 (in Japanese).

4) Kuroiwa, A. and Igarashi, Y.: Applicaton of pure titanium to metal framework, $J J p n$ Prosthodont Soc, 42(4): 547-558, 1998 (in Japanese).

5) Schilling, E. R., Miller, B. H., Woody, R. D., Miller III, A. W. and Nunn, M. E.: Marginal gap of crown made with a phosphate-bonded investment and accelerated casting method, J Prosthet. Dent 81 : 129-134, 1999.

6) Annusavice, K. J.: Phillips' science of dental materials, $10^{\text {th }}$ ed, W. B. Saunders, 1996, 484488.

7) McCabe, J. F.: Applied dental materials, $8^{\text {th }}$ ed, Blackwell Science, 1998, 43-46.

8) Zhang, Z., Ozawa, A., Tamaki, Y., Harun, M.Q., Miyazaki, T., Okazaki, Y., Takashima, H. and Hisamitsu, H.: Fundamental studies on the ammonia-free phosphatebonded binder for dental investments, J. Showa Univ. Dent. Soc. 20(3) : 322-326, 2000.

9) Zhang, Z., Tamaki, Y. and Miyazaki, T.: Experimantal ammonia-free phosphate-bonded investment using $\mathrm{Mg}\left(\mathrm{H}_{2} \mathrm{PO}_{4}\right)_{2}$, Dent Mater $J$ 20(4) : 339-344, 2001.

10) JIS T-6601 Gypsum-bonded dental investment for casting, JDMA, 1997.

11) Earnshaw, R., Morey, E. F. and Edelman, D. C.: The effect of potential investment expansion and hot strength on the fit of full crown castings made with phosphate-bonded investment, $J$ Oral Rehab $24: 532-539,1977$.

12) Hutton, J.E. and Marshall, G. W.: Expansion of phosphate-bonded investments: Part2Thermal expansion, J Prostho Dent 73(2) : 126-131, 1995.

13) Watanabe, M.: Study on phosphate bonded investment Part1 The relationship between silica particle size and thermal expansion, $J$ Dent Mat 18:12-15, 1968 (in Japanese).

14) Watanabe, M.: Study on phosphate bonded investment Part2 Dimensional and crystal changes of base and binder materials on heating and cooling, $J$ Stomatol Soc 36(3): 147-156, 1969 (in Japanese). 